\title{
How the earnings growth of US immigrants was underestimated
}

\author{
Harriet Duleep ${ }^{1} \cdot$ Xingfei Liu $^{2}$ (D) $\cdot$ Mark Regets $^{3}$
}

Received: 10 March 2020 / Accepted: 18 June 2021 / Published online: 6 November 2021

(C) The Author(s) 2021

\begin{abstract}
Two radically different descriptions of immigrant earnings trajectories in the USA have emerged. One asserts that immigrant men, following the 1965 Immigration and Nationality Act, have low initial earnings and high earnings growth. Another asserts that the post-1965 immigrants have low initial earnings and low earnings growth. We describe the methodological issues that create this divide and show that low earnings growth becomes high earnings growth when immigrants are followed from their initial years in the USA; earnings growth is allowed to vary with entry earnings; and - when following cohorts instead of individuals - sample restrictions commonly used by labor economists are avoided.
\end{abstract}

Keywords Sample restrictions · Immigrant earnings growth · Human capital investment · US census

JEL classification $\mathrm{J} 1 \cdot \mathrm{J} 2 \cdot \mathrm{J} 3 \cdot \mathrm{C} 1$

Responsible editor: Klaus F. Zimmermann

Xingfei Liu

xingfei@ualberta.ca

Harriet Duleep

hduleep@wm.edu

Mark Regets

markregets@scipolicy.com

1 Public Policy Program, GLO, IZA, College of William \& Mary, Williamsburg, USA

2 Department of Economics, GLO, IZA, University of Alberta, 8-14 Tory Building, Edmonton, Alberta T6G 2H4, Canada

3 National Foundation for American Policy, GLO, IZA, Arlington, USA 


\section{Introduction and background}

The 1965 Immigration and Nationality Act brought about the final elimination of discriminatory country-specific quotas and introduced a system of admission categories favoring immigrants with family members in the USA willing to sponsor them. ${ }^{1}$ The quota system that came into existence four decades earlier as part of the 1924 Immigration Act allocated visas according to the national-origin composition of the US population that existed in $1890 .^{2}$ Its intent was to limit most US immigration to persons from north-western Europe. ${ }^{3}$

Although largely aimed at limiting Southern and Eastern European immigrants, the 1924 quota system also restricted immigration from Africa and Asia. Moreover, several laws specifically aimed at excluding Asian immigrants already existed: the 1882 Chinese Exclusion Act, the 1907 Gentlemen's Agreement (excluding Japanese and Korean immigrants), a near-total ban on immigrants from India in 1908, and a 1917 Immigration Act that created an "Asiatic barred zone," barring migration from much of Asia and the Pacific Islands. ${ }^{4}$

The 1965 Immigration and Naturalization Act, in addition to emphasizing familybased admissions, allocated $20 \%$ of the numerically restricted visas to applicants based on their occupational skills and sponsorship by an employer. ${ }^{5}$ Thus most US immigration since 1965 has required either a family or employer sponsor, with kinship-based visas dominating.

A key issue has been determining the earnings growth of immigrant men who entered the USA following the 1965 Immigration and Naturalization Act. Three types of data are used to measure immigrant earnings growth. One approach uses a single cross-section of data, such as the 1970 Census of Population: earnings growth is measured by comparing the census-year earnings of recent immigrants with those of earlier immigrants. Another approach uses two or more cross-sections to follow "synthetic cohorts." For instance, the earnings of immigrants who entered the USA in 1965-1970 are measured by the 1970 Census and compared with the 1980 censusreported earnings of immigrants who entered the USA in 1965-70 and are 10 years

\footnotetext{
${ }^{1}$ The 1965 Immigration and Naturalization Act did impose a limit on the number of immigrants who could come from any one country, but otherwise country quotas were eliminated.

${ }^{2}$ The quota system created by the 1924 Immigration Act applied only to outside the Western Hemisphere.

${ }^{3}$ As stated by the first president of the American Economic Association: "The question to-day is ...of protecting ... the quality of American citizenship from degradation through the tumultuous access of vast throngs of ignorant and brutalized peasantry from the countries of eastern and southern Europe... Only a short time ago, [these] immigrants ... made up hardly more than $1 \%$ of our immigration. Today the proportion has risen to ... $40 \%$, and threatens soon to become fifty or $60 \%$, or even more. The entrance into our political, social, and industrial life of such vast masses of peasantry, degraded below our utmost conceptions, is a matter which no intelligent patriot can look upon without the gravest apprehension and alarm. These people have no history behind them which is of a nature to give encouragement. They have none of the inherited instincts and tendencies which made it comparatively easy to deal with the immigration of the olden time. They are beaten men from beaten races; representing the worst failures in the struggle for existence.... The problems which so sternly confront us to-day are serious enough without being complicated and aggravated by the addition of some millions of Hungarians, Bohemians, Poles, south Italians, and Russian Jews." Walker (1896).

${ }^{4}$ Refer to Bernard (1980), Hutchinson (1981), and McKenzie (1928).

${ }^{5}$ The employment-based classification embraced two components: workers, skilled and unskilled, in occupations where labor is deemed scarce, and professionals, scientists, and artists of exceptional ability.
} 
older than those in the 1970 census. Finally, longitudinal data are used to measure the earnings growth of individual immigrants.

A prevailing view among economists is that the "quality" of U.S. immigrants fell following the 1965 Act. Supporting this view are the low initial earnings of post-1965 immigrant men coupled with their apparently low earnings growth relative to US natives of similar age and education. This perspective is argued most prominently by Georges Borjas in almost all of his writings, including journal articles, ${ }^{6}$ textbooks, ${ }^{7}$ and popular books. ${ }^{8}$ Using public use microdata samples (PUMS) from the 1970 and 1980 Censuses to follow synthetic cohorts, Borjas (1985) shows much slower earnings growth for immigrants relative to U.S. natives over the 1970 to 1980 period than measured in cross-sectional analyses. Using the 1970-1990 Census PUMS data, Borjas (1995) shows that the decline in immigrant wages relative to US natives continued across consecutive immigrant waves into the 1980s, with little or no compensating earnings growth. Using 1970-2000 Census PUMS and 2009-2011 American Community Survey (ACS) data, Borjas (2015) shows low entry wages and lower wage growth for recent immigrant cohorts, relative to US natives, than for earlier cohorts.

In sharp contrast, analysts who follow individual immigrants from their initial years in the USA, and do not constrain the entry earnings/earnings growth relationship, find high earnings growth relative to US natives for post-1965 immigrant men. ${ }^{9}$ Moreover, using the same census data as Borjas, analysts who follow the earnings of synthetic cohorts from their initial years in America, let earnings growth vary with entry earnings, and do not exclude zero earners, students, or the self-employed find high earnings growth for post-1965 immigrants. ${ }^{10}$

This paper illuminates the methodological issues that create such starkly different pictures of post-1965 immigrant economic assimilation. We show that the predominant methods economists use to measure immigrant economic assimilation tend to underestimate the earnings growth of immigrants who start with low earnings relative to US natives of similar age and education. These methods include:

(1) Following immigrants in all possible year-of-entry cohorts, versus following only those who can be tracked from their initial years in the USA;

(2) Combining all possible year-of-entry immigrant cohorts to estimate earnings growth, versus separately following each entry cohort;

(3) Constraining the relationship between immigrant entry earnings and earnings growth to be the same for all year-of-entry cohorts, versus letting earnings growth vary with entry earnings;

(4) Controlling for education using the schooling levels of immigrants years after their U.S. entry, versus their education at entry; and

\footnotetext{
${ }^{6}$ Examples include, Borjas (1985, 1994, 1995, 2015) and Borjas and Tienda (1987).

${ }^{7}$ Examples include Borjas (2014, 2016, 2020).

${ }^{8}$ Examples include Borjas (1999, 2000).

${ }^{9}$ Refer to Duleep and Regets (1997), Duleep and Dowhan (2002), Hall and Farkas (2008), and Villarreal and Tamborini (2018). Analyses of occupational mobility with longitudinal data further suggest economic assimilation for post-1965 U.S. immigrants (e.g., Akresh 2006, 2008; Chiswick 1978b), and for Australian immigrants (Chiswick et al. 2005).

${ }^{10}$ Refer to Duleep and Regets $(1994,2002)$.
} 
(5) In studies that follow synthetic cohorts instead of individuals, excluding students, the self-employed, and zero earners.

Methods 1 through 4 underestimate the earnings growth of immigrants who start with low initial earnings regardless of whether researchers follow synthetic cohorts or use longitudinal data to follow individuals. For instance, using longitudinal data on individuals, Hu (2000) and Lubotsky (2007) misrepresent the earnings growth of immigrants by estimating a model that constrains the relationship between immigrant entry earnings and earnings growth to be the same for all year-of-entry cohorts. Method 5 underestimates immigrant earnings growth in studies that follow synthetic cohorts.

The plan of the paper is as follows. Section 2 uses longitudinal data on individuals to show how constraining the relationship between entry earnings and earnings growth (the fixed-cohort-effect method) leads to underestimates of earnings growth for immigrants who start their US journeys with low initial earnings. Section 3 describes the effect on earnings-growth estimates of using current levels of schooling (versus the level of schooling immigrants had entering the USA) to control for education. Section 4 reveals how, when analysts follow synthetic cohorts across censuses (or other crosssectional datasets), commonly used sample restrictions distort earnings growth estimates of immigrants, relative to natives. Section 5 broaches measuring immigrant skill transferability and whether earnings growth represents human capital investment. The conclusion summarizes our results and notes societal ramifications of high immigrant earnings growth.

\section{The importance of the inverse relationship between entry earnings and earnings growth}

The first labor-economics studies, initiated by Chiswick (1978a, 1979), use a single year of census data to measure immigrant earnings growth. Adjusting for demographic and human capital characteristics, the difference between the initial earnings of recent immigrants and the earnings of earlier immigrants measures earnings growth. The cross-sectional approach suggests that immigrant men have low initial earnings but high earnings growth, substantially exceeding the earnings growth of US natives.

This optimistic picture was challenged when Borjas (1985, 1987, 1992a, 1992b, 1994), using multiple censuses, measured a steep decline in the entry earnings of immigrant men that persists controlling for immigrant-native differences in schooling and age. The decline is most apparent since 1965 when US immigration policy shifted from a national-origins system, favoring northwestern European immigration, to a family-based policy that altered the source-country composition of US immigration.

Borjas found that immigrants who entered the USA in the decades immediately preceding the 1965 Act did not start their US journeys with lower earnings than natives of similar age and education. Nor did they experience higher earnings growth than natives. Evidently, the cross-sectional estimates of high earnings growth stemmed from pairing the low entry earnings of more recent immigrants with the unvaryingly high earnings of earlier immigrants. 
The dramatic decline in the adjusted entry earnings of immigrant men inspired a new methodology for measuring immigrant earnings growth. Now standard practice, the fixed-cohort-effect method (Borjas 1985) is in labor economics textbooks (e.g., Benjamin et al. 2017; Bodvarsson and Van den Berg 2013; Borjas 1999, 2016, 2020) and used by most economists with various types of data, including synthetic cohorts and longitudinal data on individuals.

As in the cross-sectional approach, the fixed-cohort-effect method estimates immigrant earnings growth in an earnings regression by statistically measuring the relationship between years since migration and immigrant earnings, controlling for age and years of schooling. It adds to the equation categorical (zero-one) variables for each year-of-entry cohort thereby allowing the estimated relationship between years since migration and earnings to begin at different levels of initial earnings, while implicitly assuming that earnings growth does not change with changing levels of initial earnings. The fixed-cohort-effect method thus abandons one assumption of the cross-sectional method - inter-cohort constancy in immigrants' adjusted entry earnings - while retaining another-inter-cohort constancy in earnings growth. ${ }^{11}$

Had Borjas' empirical methodology followed the human-capital-investment perspective introduced by Chiswick (1978a, 1979), the discovery of a decline in immigrant initial earnings might have inspired a methodology permitting both entry earnings and earnings growth to vary. Instead, Borjas (1987, 1992a-c, 1994) proposed that the decline in adjusted entry earnings stems from a decline in immigrant ability. Conceivably, changes in immigrant ability could affect entry earnings without affecting earnings growth. ${ }^{12}$

In contrast, a human-capital-investment perspective predicts that (controlling for initial levels of human capital) decreases in initial earnings systematically accompany increases in earnings growth, and vice versa. ${ }^{13}$ Empirical evidence supports this prediction. Following nearly a hundred country-of-origin cohorts, first with the 1960-1980 censuses, and then with the 1970-1990 censuses, Duleep and Regets (1994, 2002) document a strong inverse relationship between entry earnings and earnings growth, controlling for years of schooling and age. This finding, which

\footnotetext{
${ }^{11}$ Borjas introduced the fixed cohort-effect methodology to address cross-sectional bias, as first articulated and analyzed in Chiswick (1980). In what appears to be the first use of longitudinal individual data to study immigrant earnings, Chiswick measured earnings growth with the National Longitudinal Survey of Adult Males, following the earnings of immigrants who had entered the U.S. in various years. He then compared this earnings growth with a cross-sectional estimation on the same data. The two estimates were similar; Chiswick concluded that cross-sectional bias was not a problem. What Chiswick did not consider was that immigrants' initial earnings, controlling for education and experience, had declined over time. If earnings growth increases as entry earnings decrease, then earnings growth estimates from cross-sectional and longitudinal data will be similar.

${ }^{12}$ Borjas (1987) suggests that a post-1965 increase in the income inequality of the countries contributing to U.S. immigration fueled a decline in immigrant ability. It is theoretically ambiguous whether lower ability leads to lower initial earnings: ceteris paribus, high ability individuals should invest in more human capital than low ability individuals thereby lowering the former group's initial earnings. Under any human capital model, however, a decline in labor-market ability would not increase earnings growth. According to the income-distribution/immigrant-ability explanation, immigrant earnings growth should have declined or stayed constant as immigrant entry earnings declined. The latter is consistent with the fixed-cohort-effect methodology (Borjas 1985).

${ }^{13}$ Refer to Chiswick (1978a, 1979), Duleep and Regets (1994, 2002), Duleep et al. (2018), and Duleep et al. (2021a).
} 
resonates with other research that predicts or finds an inverse relationship, ${ }^{14}$ suggests specific strategies for measuring immigrant earnings growth.

Economists typically use all possible year-of-entry cohorts in their analyses, including those for which the available earnings information begins years after immigrants' initial year of entry. Yet, to avoid implicit assumptions about the relationship between entry earnings and earnings growth, analysts should (ideally) include only year-of-entry cohorts that can be followed from immigrants' initial host-country years. Though reducing the information that is used, this approach ensures that results do not reflect an assumed relationship between immigrants' initial earnings and earnings growth. ${ }^{15}$

Economists also typically combine all year-of-entry cohorts into a single estimation. Since cohorts that vary in their entry-level earnings systematically vary in their earnings growth, analysts should (at least initially) examine each year-of-entry cohort separately.

Limiting their analysis to entry cohorts, following each year-of-entry cohort separately, allowing both entry earnings and earnings growth to vary, and avoiding sample restrictions, the census-based studies of Duleep and Regets $(1994,2002)$ find that the earnings trajectories of immigrant men who entered the USA prior to or just after the 1965 Immigration Act resemble the earnings trajectories of natives. ${ }^{16}$ Subsequent cohorts start at lower earnings and have higher earnings growth than natives.

Using longitudinal earnings data matched to the 1994 Current Population Survey (CPS), Duleep and Dowhan (2002) follow immigrant men from their initial US years relative to natives weighted to have the same age and education distribution as immigrants. Immigrants entering in 1960-1964 and 1965-1969 have initial earnings that are higher than subsequent cohorts and earnings growth resembling that of US natives. Starting with the 1970-1974 cohort, the initial earnings of immigrant men fall relative to their US-born statistical twins, and their earnings growth grows.

To illustrate, the solid lines of Fig. 1 show, for each year-of-entry cohort, median immigrant earnings divided by median US-born earnings measured in the immigrants' initial year and 10 years later. ${ }^{17}$ These studies confirm Borjas' finding that when the initial adjusted earnings of immigrants fall over time, the cross-sectional method (pairing the entry earnings of a recent cohort with the earnings measured in the same year of an earlier cohort) overstates the earnings growth of earlier immigrant cohorts. It does not follow, however, that the earnings growth of earlier cohorts predicts the earnings growth of more recent cohorts.

\footnotetext{
${ }^{14}$ Chiswick (1978a, 1979) first predicted the inverse relationship with supporting evidence that U.S. immigrants from non-English-speaking countries had lower initial earnings but higher earnings growth than immigrants from English-speaking countries. Other confirmatory evidence includes Lalonde and Topel (1991, 1997), Duleep and Regets (1994, 1997, 1999, 2002), Jasso and Rosenzweig (1995), DeSilva (1997), Schoeni (1997), Demombynes (2002), Aydemir and Skuterud (2005), Akresh (2007), Green and Worswick (2012), Lin (2013), Villarreal and Tamborini (2018), Duleep et al. (2018), and Duleep et al. 2021b.

${ }^{15}$ It also avoids confounding effects of age and assimilation and the choice of an appropriate reference group (Kossoudji 1989; Lalonde and Topel 1991, and Friedberg 1992).

${ }^{16}$ Immigrants coming from countries whose immigration was severely restricted prior to 1965 lacked families in the U.S. The initial post-1965 entrants were thus more likely to enter the U.S. on employment-based visas than was subsequently the case (Duleep et al. 2021a). This likely explains their higher entry earnings and lower earnings growth than subsequent cohorts.

17 The solid-line estimates are based on Table 2, panel C, adjusted results of Duleep and Dowhan (2002, p. 491). To be in the sample, positive earnings are required in the first and tenth year.
} 


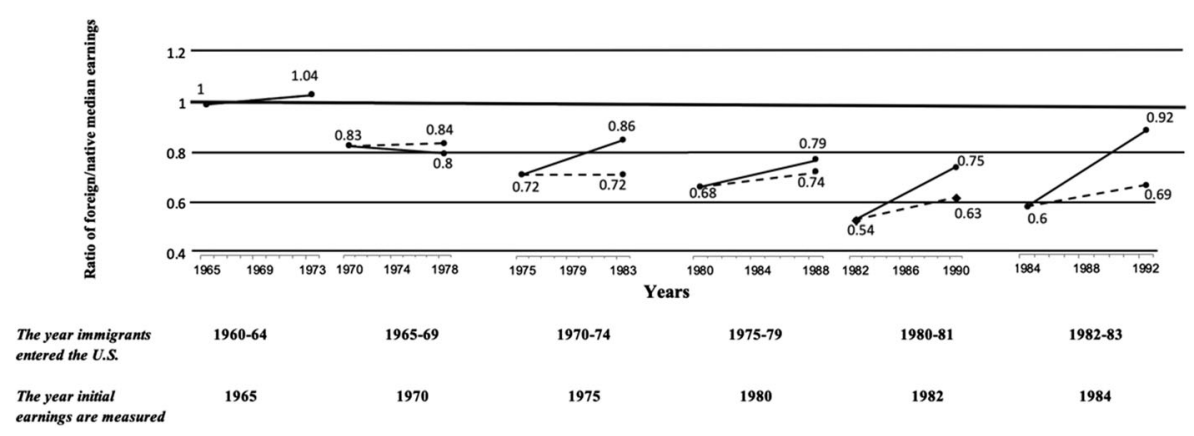

Fig. 1 Adjusted foreign-born annual earnings relative to native-born annual earnings measured at the median in the 1st and 10th year following immigrants' CPS reported year of entry. Notes: Men are at least 25 years old in the first year and no more than 60 years old in the tenth year. Immigrant cohorts are defined by the 1994 CPS-reported year of entry. The solid lines represent the earnings growth estimated for each cohort. The dashed lines represent earnings growth averaged across current and prior cohorts

In estimating the earnings growth of immigrants, the fixed-cohort-effect method averages the earnings-growth rates of all of the year-of-entry cohorts. This is not a bias issue; the estimate may be unbiased. Nevertheless, with overtime decreases in immigrants' adjusted initial earnings, averaging earnings growth across cohorts misrepresents the earnings growth of cohorts that start with relatively low entry earnings.

The dashed lines in Fig. 1 project the earnings trajectories of immigrants relative to natives using each cohort's earnings growth averaged with the earnings growth of preceding cohorts. The average earnings-growth projections understate actual earnings growth, shown with solid lines, for all of the post-1965-1969 cohorts. For instance, in 10 years, the median earnings of immigrants who reported coming to the USA in 19821983 go from $60 \%$ of the median earnings of natives, weighted to have the same age and education distribution as the foreign-born, to $92 \%$ of US natives' earnings. With earnings growth averaged over the current and preceding cohorts, their earnings in 10 years go from 60 to $69 \%$ of US natives' earnings. ${ }^{18}$

Because of the inverse relationship between entry earnings and earnings growth, when immigrant entry earnings fall over time, cross-sectional analyses may outperform fixed-cohort-effect estimates of the earnings growth of more recent immigrant cohorts. Note the similarity in the cross-sectional and cohort-based estimates in Chiswick (1986). This is because increasing earnings growth partially or fully compensates for lower entry earnings. When earnings growth fully compensates, immigrants starting with lower entry earnings achieve the same earnings as earlier cohorts starting at higher entry earnings. The correspondence occurs because of the inverse relationship between the age- and education-adjusted entry earnings of immigrants and their earnings growth.

Figure 1 measures "initial" earnings 1 to 5 years after the period in which immigrants reported to the CPS that they had come to the USA Fig. 2 defines year-of-entry cohorts by when earnings first appear in Social Security's record system (Duleep and

\footnotetext{
${ }^{18}$ Borjas $(1985,1995,1999,2016,2020)$ uses the fixed cohort-effect model with census data synthetic cohorts; $\mathrm{Hu}$ (2000) and Lubotsky (2007) use it with longitudinal data on individuals. Borjas (2015) allows earning growth to vary across immigrant cohorts and still finds slow earnings growth for recent immigrants relative to U.S. natives of similar age and education levels. Section 4 explains why.
} 
Dowhan 2002). Although starting at various beginning points, the year-of-entry cohorts converge to the same relative earnings point. ${ }^{19}$

\section{Controlling for immigrant education levels measured years after US entry}

In measuring the earnings growth of immigrants relative to natives, economists typically control for the level of education reported in the survey year. Controlling for current education likely depresses estimates of immigrant earnings growth. Immigrants who invested in more education have their post-education earnings compared not to the previous earnings of a similar person holding their old education level, but to someone who already held the new education level in the previous period. The earnings growth estimate for individuals who did not get more education will also be biased downwards since their later earnings will be grouped with those who had just recently obtained the same education level.

As an example, analysts who want to measure the earnings growth of immigrants admitted with high-school degrees will be misled by comparing the average earnings of an entry cohort with high-school degrees in one period with those of high school graduates from the same cohort 10 years later. Some of the high-school graduates in the second period will have earned their diploma during those 10 years and many high school graduates in the first period will now have higher education.

Chiswick (1986), p. 188) noted the bias in earning growth estimates when controlling for education and comparing two groups with different rates of school attendance:

... the earnings analyses here and in Borjas (1985) bias downward the cohort increase in earnings over the decade by controlling for schooling level in the same year as the earnings data, rather than schooling level in 1970. While this downward bias occurs for all groups, it is likely to be more intense for Cuban and other refugees as they invest in more post immigration schooling. Thus, the downward bias in the estimated growth of earnings would be greater for the Cubans than for other whites.

To the extent that immigrants invest more in schooling than natives, controlling for education using schooling levels immigrants achieved years after their immigration will understate immigrant earnings growth. Using the 1990 Census PUMS (Fig. 3) and the 2018 American Community Survey (Fig. 4), we estimate the percent in school by age for US-born men and for immigrants, 1 to 5 years after their immigration. Both the 1990 and 2018 data show higher levels of school attendance for immigrants than for natives. ${ }^{20}$

\footnotetext{
${ }^{19}$ A concern may be that variation in the initial-year earnings reflects variation in the extent to which there are partial-year earnings from newly arrived immigrants. Nevertheless, the finding of convergence holds when defining the cohort from the first year, and measuring earnings starting with the second year.

${ }^{20}$ The 2018 comparison shows recently arrived immigrants closer to U.S. natives in their school attendance than in 1990. This difference does not necessarily mean anything since the 2018 question differs from the 1990 question. For instance, the 1990 question did not include enrollment in a trade or business school, company training, or tutoring; no similar restriction exists in the 2018 ACS question. The changes could differentially affect measurement of immigrant versus native school attendance.
} 


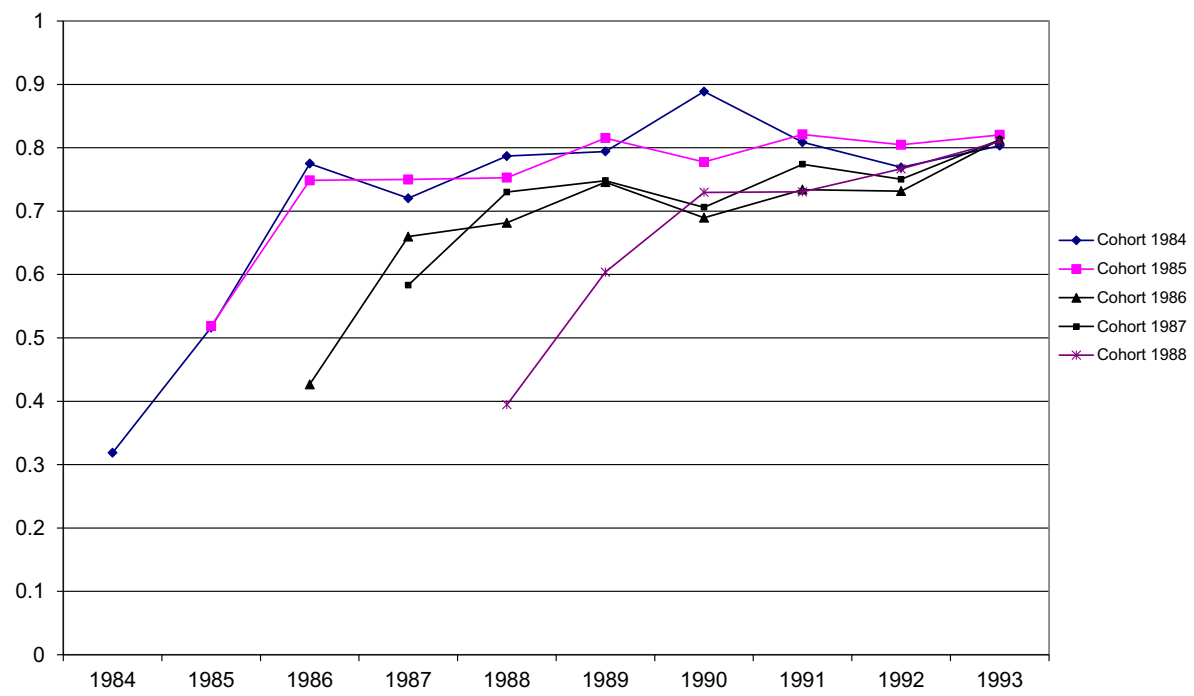

Fig. 2 Adjusted foreign-born relative to native-born annual median earnings: cohorts defined by first evidence of earnings in Social Security administrative record data. Source: Duleep and Dowhan (2002, Fig. 6, p. 503). Notes: Men are at least 25 years old in the first year and no more than 60 years old in 1993

Because of the downward bias that using current education levels likely causes, analysts who want to control for education in their earnings estimations should ideally use education levels near immigrants' year of entry. It is possible to do this with longitudinal data when following the same individuals. When following cohorts, the best one can do to mitigate the downward bias is to control for education in broad categories.

\section{Sample restrictions: the effect of excluding students, zero earners, and the self-employed}

Scholars agree that in following cohorts, immigrant emigration can bias measures of immigrant earnings growth by altering the composition of the samples being compared (e.g., Lubotsky 2007). ${ }^{21}$ Yet, no similar concern is voiced about commonly used sample restrictions-excluding students, zero-earners, and the self-employed.

This is not a problem limited to studies of immigrants. Whenever sample restrictions are applied to individuals in two different periods, it is likely that many individuals included in one period will be excluded in the other. In longitudinal data, one can exclude an individual from the data for both periods-technically maintaining a consistent sample universe, but possibly

\footnotetext{
${ }^{21}$ Following the same individuals, as in Duleep and Regets (1997) and Duleep and Dowhan (2002), eliminates selective emigration as a spurious contributor to earnings-growth estimates.
} 


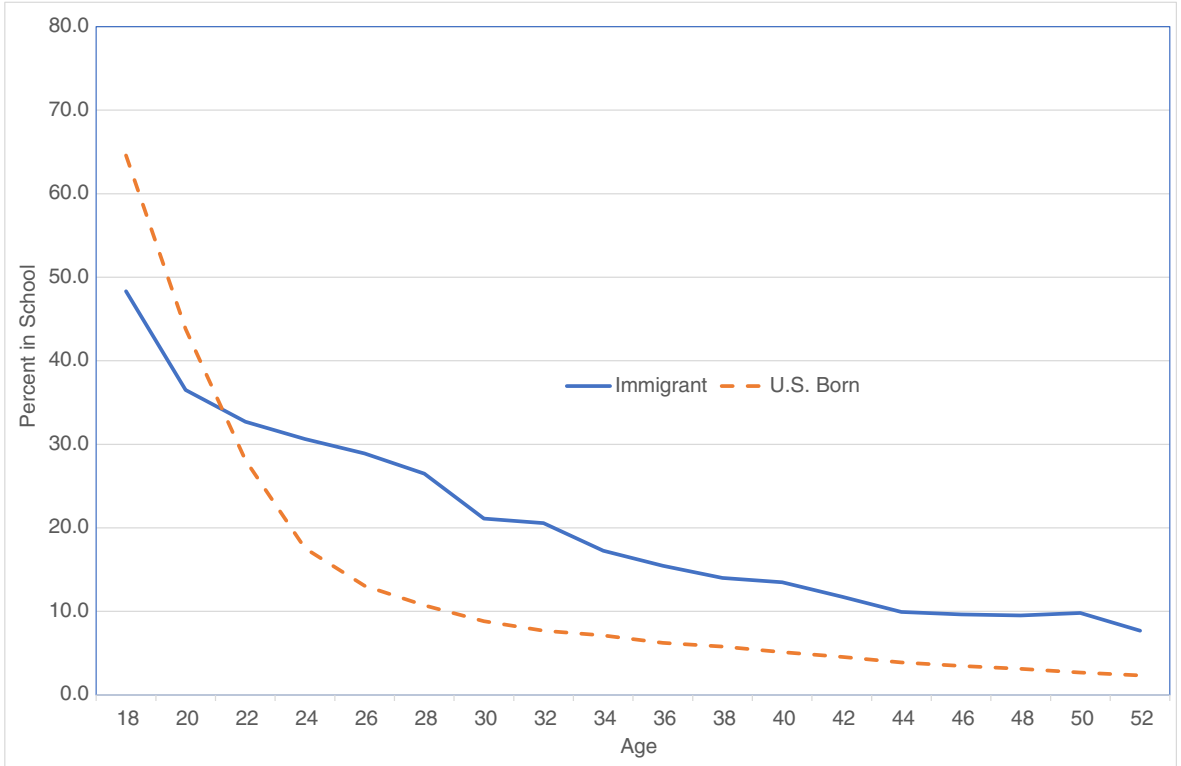

Fig. 3 Percent in school by age: Immigrants 1 to 5 years after entry and U.S.-born men. Notes: Estimates based on 1990 Census PUMS 5\% sample

excluding people of analytic and policy interest. When comparing a cohort of individuals across two censuses, there is usually no way to know if a person would have qualified for the universe being analyzed in both periods.

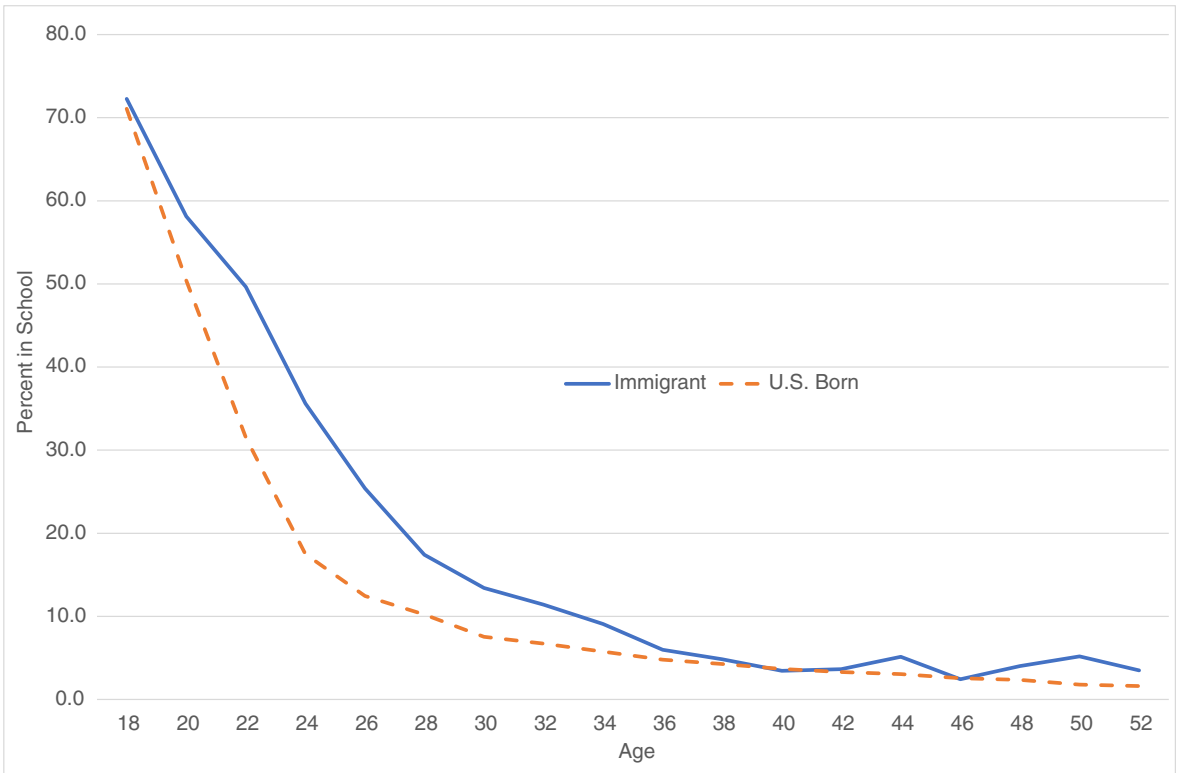

Fig. 4 Percent in school by age: Immigrants 1 to 5 Years After Entry and U.S.-born men. Notes: Estimates based on 2018 ACS 
Consider the case of individuals excluded from an initial sample because they are unemployed or out of the labor force (perhaps because of job search or time spent in school), but fully employed and hence included, in a subsequent sample. Individuals may also move from wage and salary jobs (thereby included in the first sample) to self-employment (thereby excluded). While these issues apply to any cohort followed between censuses (or other data sources), they may be particularly important for the study of immigrant earnings growth because immigrants have high occupational mobility, high in-school rates, and, for some groups, high self-employment rates. ${ }^{22}$

Beyond the effect of sample restrictions on directly measuring immigrant earnings growth, labor economists usually measure the earnings growth of immigrants relative to natives. Dividing foreign-born by native-born earnings controls for price movements and changes in the economy. Nevertheless, sample restrictions that differentially affect the estimated earnings growth of immigrants and natives distort the estimated relative earnings growth of immigrants. We illustrate this problem with three hypothetical examples and follow with empirical evidence.

\subsection{How sample restrictions could downward bias the estimated relative earnings growth of immigrants: theoretical expectations}

Figure 5 presents three hypothetical earnings trajectories for both immigrants and natives measured from immigrants' initial years in the USA (year 1) to 10 years later (year 10). It illustrates only three of many possible scenarios where sample exclusions can distort estimates of the growth rate of immigrant earnings themselves, and the growth rate of immigrant earnings relative to natives.

To simplify the exposition and isolate the effect of sample restrictions, Fig. 5 assumes that, sans sample restrictions, natives and immigrants have the same earnings growth. It further assumes that a given restriction has differing proportional effects in the two periods for only immigrants (top and middle tier of Fig. 5) or only natives (bottom tier).

Median earnings measured from the unrestricted and restricted samples are $Y_{u}$ and $Y_{r}$, respectively. $\left(Y_{r}-Y_{u}\right)_{1}$ is the difference in estimated median earnings between the restricted and unrestricted samples at year $1 ;\left(Y_{r}-Y_{u}\right)_{10}$ is the difference at year $10 .^{23}$ The earnings trajectories estimated with unrestricted samples are solid lines; those estimated from restricted samples are dashed. In a synthetic cohort, there is no way to apply a sample restriction to an individual's status in both periods. A person outside the labor force in period 1 may be working full-time in period 2. Thus, a person

\footnotetext{
${ }^{22}$ For occupational mobility see, for instance, Akresh (2006, 2008), Chiswick (1978b), Chiswick et al. (2005), Chiswick and Miller (2008), Green (1999), Jasso and Rosenzweig (1990, 1995), and Zorlu (2013). For educational investment see, for instance, Duleep and Regets (1999, 2002), Chiswick and DebBurman (2004), Van Tubergen and van de Werfhorst (2007), and Jasso and Rosenzweig (1990). For self-employment see, for instance, Lofstrom $(2000,2002,2011)$.

${ }^{23}$ Note that if $\left(Y_{r}-Y_{u}\right)_{1}=\left(Y_{r}-Y_{u}\right)_{10}$ then the estimated earnings growth is unaffected by the sample restriction. As a practical matter this is unlikely to occur, but to simplify our scenarios this is the case for the top and middle tier graphs for natives and the bottom tier graph for immigrants in Figure 5
} 
Immigrants

올

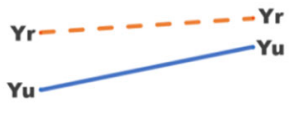

1

Year

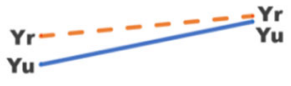

1

Year

บัำ

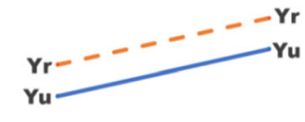

1

Year

Natives

แึ

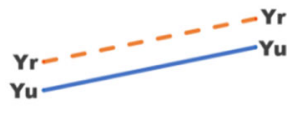

10

Year
Scenario 1:

Excluding students increases $Y 1$ more for immigrants than for natives.

Scenario 2:

Excluding zero earners decreases Y10 more for immigrants than for natives.

Scenario 3: Excluding zero earners increases Y10 more for natives than for immigrants.

Fig. 5 How excluding students and zero earners from the sample could bias estimates of immigrant relative earnings growth: Three hypothetical scenarios. Notes: $Y_{U}$ are earnings estimated on unrestricted samples; $Y_{r}$ are earnings estimated on restricted samples. The solid lines denote hypothetical earnings trajectories based on unrestricted samples; the dashed lines represent earnings trajectories based on restricted samples

selected as eligible for the sample in period 2 may have been ineligible in period 1 , or vice versa. $^{24}$ The whole point of a synthetic cohort is to assemble two samples of similar individuals, but sample restrictions can create two samples of individuals who are following very different career paths.

\subsubsection{Hypothetical scenario 1}

Ceteris paribus, the earnings growth of immigrants relative to natives, will be underestimated if a sample exclusion increases earnings in year 1 relative to year 10 more for immigrants than for natives. In other words, immigrant relative earnings growth is biased downwards to the extent that $\left[\left(Y_{r}-Y_{u}\right)_{1}-\left(Y_{r}-Y_{u}\right)_{10}\right]$ is greater for immigrants than for natives. This situation, depicted in Fig. 5's top tier, could occur when students are excluded from samples.

\footnotetext{
${ }^{24}$ It is usually possible to make such restrictions in longitudinal data, but creates other problems only indirectly addressed by this paper - it may be possible to make unbiased growth estimates over the universe you define, but that universe may itself be unrepresentative of the population of policy interest.
} 
Excluding students from any sample will increase median (or average) earnings to the extent that students do not work, or work in lower-paying part-time jobs. Because immigrants are initially more likely to attend school than natives, we would expect that excluding students would increase initial earnings relative to year-10 earnings more for immigrants than for natives, thus biasing downward foreign-born relative earnings growth.

We would further expect this downward bias to be most prevalent for more highly educated immigrants. Although the effect of education on human capital investment is ambiguous in most human capital investment models (by increasing both the productivity and opportunity cost of human capital investment), in the Immigrant Human Capital Investment model (Duleep and Regets 2002), education that does not transfer to the labor market (and thus does not raise the opportunity cost of human capital investment) is useful for learning new skills.

We would therefore expect school attendance by immigrants, relative to natives, to increase with initial education levels. ${ }^{25}$ The greater the immigrant/native differential in attending school, the greater the likelihood that excluding students from the sample negatively biases the relative earnings growth of immigrants.

\subsubsection{Hypothetical scenario 2}

Foreign-born relative earnings growth will be underestimated if a sample exclusion increases earnings in year 10 relative to year 1 less for immigrants than for natives. In other words, immigrant relative earnings growth is biased downwards to the extent that $\left[\left(Y_{r}-Y_{u}\right)_{10}-\left(Y_{r}-Y_{u}\right)_{1}\right]$ is less for immigrants than it is for natives. This situation, depicted in Fig. 5's middle tier, could occur when zero earners are excluded from samples.

Excluding zero earners will raise average earnings in year 1 and year 10 for both immigrants and natives. Yet, holding other factors constant, we would expect the year10 increase, relative to the year-1 increase, to be less for immigrants than for natives.

When researchers exclude zero earners from their samples, they are very likely to include in the second-period sample individuals who previously had zero earnings in the first period. Even if the typical 10 years between earnings measurements is enough for immigrants with initial skill-transferability problems to earn the same as natives, their exclusion from the first period downward biases earnings-growth estimates. Immigrants will be more likely than natives to go from zero earnings in the first period to positive earnings in the second period, particularly among those with the highest propensity to invest in human capital-immigrants who initially lack transferable skills but have relatively high levels of schooling and are young (Duleep and Regets 2002).

\subsubsection{Hypothetical scenario 3}

Foreign-born relative earnings growth will be underestimated if a sample exclusion increases earnings in year 10 relative to year 1 more for natives than for immigrants. This situation, depicted in Fig. 5's bottom tier, is another way excluding zero earners could lower estimates of foreign-born relative earnings growth.

$\overline{{ }^{25} \text { For empirical evidence on this, }}$ refer to Betts and Lofstrom (2000). 
If, controlling for age and education, those who stop working had lower wages prior to leaving the labor force than men who continue working, then excluding zero earners would, in 10 years, create a group with higher wages. For a variety of reasons, we would expect less of a labor force dropout for immigrant men than for US natives. To the extent that this is true, studies that exclude zero earners will be comparing immigrants to a more select group of natives at the 10 -year point than at the firstyear point, thereby depressing the estimated relative earnings growth of immigrants.

\subsection{The effect on immigrant relative earnings growth of excluding students, zero earners, and the self-employed: empirical evidence}

To explore empirically the effect of excluding students, zero earners, and the selfemployed on the relative earnings growth of immigrant men, we use the Census data that Borjas (2015) uses - the public use micro Census data extracted from the 1970, 1980, 1990, and 2000 censuses and the 2010 American Community Survey (ACS). ${ }^{26}$ We define immigrants as persons born outside of US soil who are either naturalized citizens or noncitizens $^{27}$ and US natives as persons born on US soil who are US citizens. ${ }^{28}$

As in Borjas (2015), we measure earnings with weekly earnings calculated by dividing annual earnings by weeks of work. Annual earnings include wage and salary income, non-farm business income, and farm income. ${ }^{29}$ Weeks of work measure the number of weeks the respondent worked for pay during the previous year. ${ }^{30}$ (For those who report zero weeks of work, weekly earnings are defined as zeros and included in our unrestricted sample described below.) ${ }^{31}$

\footnotetext{
${ }^{26}$ Our 1970 census data include the following three random samples: $1 \%$ state sample $+1 \%$ metro sample + $1 \%$ neighborhood sample (all from form 1). 1980 census data include: $5 \%$ state sample $+1 \%$ metro sample + $1 \%$ urban/rural sample $+1 \%$ labor market areas sample $+1 \%$ metro/non-metro sample. 1990 census data include: $5 \%$ state sample $+1 \%$ metro sample. 2000 census data include: $5 \%$ sample $+1 \%$ sample. Finally, we use the 2010 American Community Survey (ACS). Sample weights are used in all analyses, in particular, for example, for the 1980 sample, the individual sample weight is constructed by dividing the census weight by the number of representative samples used in each census year: 5 samples from 1980 are used.

${ }^{27}$ U.S. soil includes U.S. outlying areas/territories, for example, American Samoa, Guam, Puerto Rico, U.S. Virgin Islands and other U.S. possessions. Non-citizen includes those who had begun the naturalization process but not those who were born abroad of American parents.

${ }^{28}$ Our definition of U.S. natives does not include those who were born abroad of American parents. Therefore, neither immigrants nor natives include people born abroad of American parents according to our definition.

${ }^{29}$ Earning data were top coded for census years 1970 and 1980 at $\$ 50,000$ and $\$ 75,000$, respectively. Following Borjas (2015), we multiply the top-coded earnings by 1.5. On the 1990 and 2000 IPUMS data file, income above the top codes ( $\$ 140,000$ and $\$ 175,000$ respectively) is reported as the median of all income in an individual's state who are above the top code. Lastly, for 2010 ACS, earnings above the 99.5 th percentile in the state are replaced by the state means above that value.

${ }^{30}$ Only categorical data were available for "weeks worked last year" in the 1970 census and the 2010 ACS. Following Borjas (2015), we use the median value within each interval. In particular, for people who report working between 1 and 13 weeks, we use 8 weeks.

${ }^{31}$ In constructing weekly earnings, we closely follow Borjas (2015). There are, however, a few differences. Borjas (2015) uses proportion of working weeks in a year to further weight individual observations. Specifically, Borjas (2015) takes the product of "the census provided individual sample weight" and "the share of the working weeks" as the weight to generate empirical results. Other than using the census provided sample weight, we do not further weight our sample by working intensity. Borjas (2015) uses log of weekly earnings, which automatically removes zero earnings. In our unconstrained samples, we do not remove individuals with zero earnings or zero weeks of work. We only use the census weight even when zero earners are excluded.
} 
Limiting our analysis to immigrant cohorts that can be followed from their initial years in the USA, we analyze each entry cohort separately. Our entry cohorts for immigrants are persons who came to live in the USA within the last 5 years of each census year. We follow immigrant cohorts, defined by year of arrival, with consecutive censuses for 10 years.

We separate each cohort by age: a younger group, 25 to 39 years old in the initial census and 35 to 49 in the next census, and an older group, 40 to 54 in the initial census and 50 to 64 in the next census. We further separate by education level: above high school (persons who completed thirteen or more school years) and high school and below (persons who completed less than thirteen school years). For instance, for the 1970 census the younger, more educated cohort includes immigrants who were 2539 years old in 1970, arrived between 1965 and 1970, with thirteen or more school years in 1970; using 1980 census data, the same cohort is 35-49 in 1980, arrived within the last 10-15 years, with thirteen or more school years in 1980 .

Within age and education groups, we measure weekly earnings of foreign-born men relative to US-born men in one census and then for the same cohort 10 years later, in the subsequent census. Immigrant relative weekly earnings are calculated by dividing the median weekly earnings of immigrants in an age/education cell by the median weekly earnings for US natives from the same age/education cell. Our approach is nonparametric - the relationship between immigrant entry earnings and earnings growth is not constrained in any way. We also, initially, do not restrict the sample in any way. These earnings trajectories provide unconstrained baselines.

We then exclude students, the self-employed, and zero earners from our samples and again measure initial median earnings and median earnings 10 years hence. We learn the effect of sample restrictions by comparing the earnings trajectories based on unrestricted versus restricted samples. Since we compare the estimates for each cohort over the same 10 years, all earnings' data are in current US dollars.

The solid line in each year-of-entry/age/education graph of Fig. 6 represents the estimated growth of median weekly earnings for foreign-born men relative to US-born men with no sample restrictions. The dashed line represents the relative earnings of immigrants when we exclude the self-employed, students, and zero earners. Figure 6 reveals that in almost all age/ education/year-of-entry cohorts, the relative earnings growth of immigrants based on unrestricted samples exceeds the earnings growth based on restricted samples.

\subsection{The separate effects of excluding students, zero earners, and the self-employed}

In results not shown, we examine the individual effect of each sample restriction on immigrants' relative earnings growth. That is, what is the effect on foreign-born relative earnings growth of only excluding the self-employed, or only students, or only zero earners?

Excluding the self-employed barely nudges the relative weekly earnings growth of immigrants in most age/education/year-of-entry cohorts ${ }^{32}$; when it does have an effect, it slightly increases relative foreign-born earnings growth. Borjas (1985, 1994, and 1995) excludes students, the self-employed, and zero earners; Borjas (2015) excludes students and zero earners.

\footnotetext{
32 The fact that excluding the self-employed has little effect on our measures of immigrant relative earnings growth may reflect the fact that our analyses include all immigrants. Immigrant groups vary in their selfemployment rates. The effects of excluding the self-employed on immigrant earnings growth measured for particular groups, relative to all natives, may differ dramatically from our all-immigrant/all-native analyses.
} 


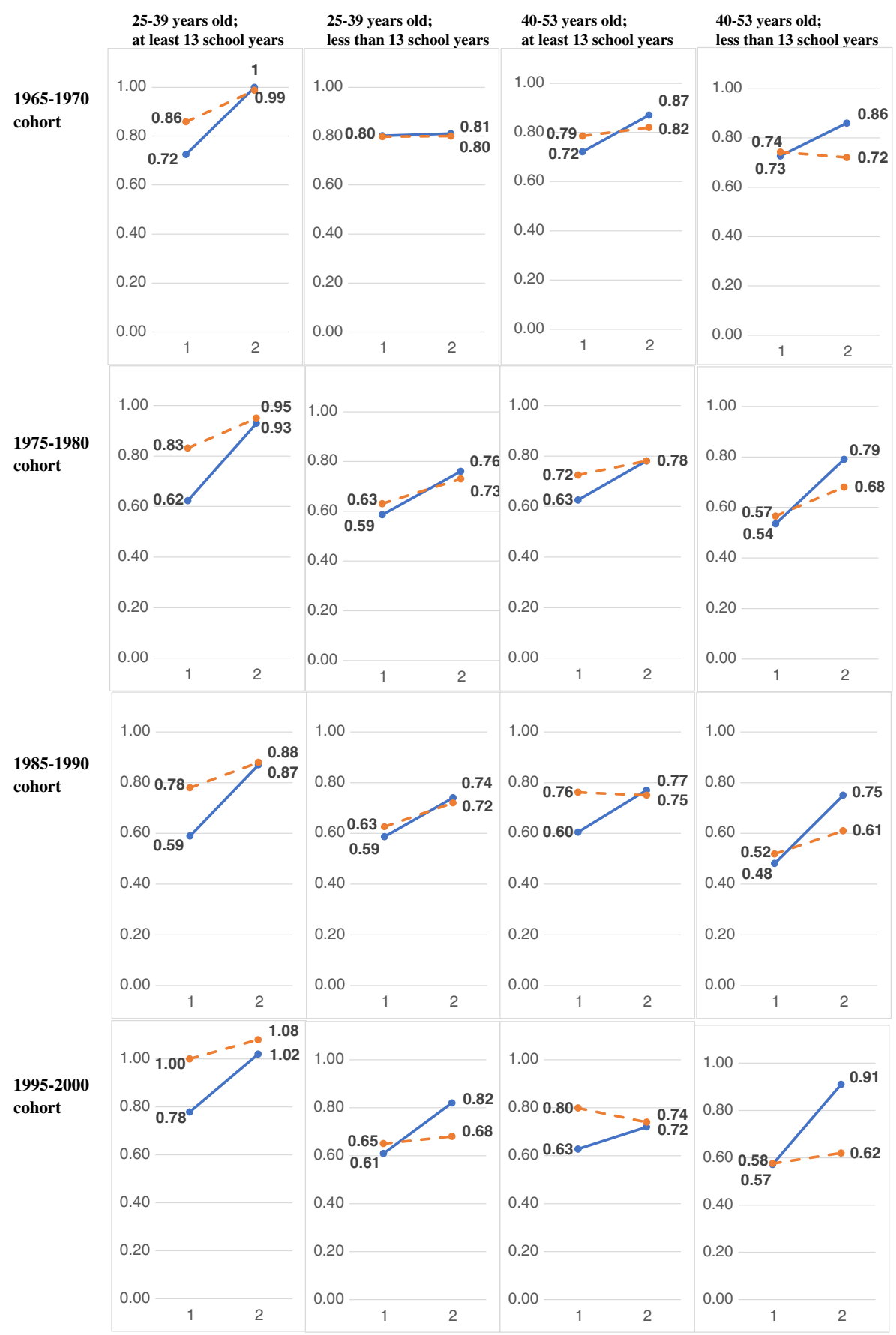

Fig. 6 The ratio of foreign-born to native-born median weekly earnings measured at 1 to 5 years after US entry and 10 years later: No sample restrictions (solid line) versus all sample restrictions (dashed line) 
Table 1 The effect of excluding students on median weekly earnings for immigrants, measured 1 to 5 years after entry and 10 years later, and for U.S. natives

Men who completed 13 or more school years and were 25-39 years old at the time of the initial census

\begin{tabular}{|c|c|c|c|c|c|c|c|c|}
\hline \multirow[b]{2}{*}{ Foreign born } & \multicolumn{2}{|c|}{$\begin{array}{l}1965-70 \\
\text { cohort }\end{array}$} & \multicolumn{2}{|c|}{$\begin{array}{l}1975-80 \\
\text { cohort }\end{array}$} & \multicolumn{2}{|c|}{$\begin{array}{l}1985-90 \\
\text { cohort }\end{array}$} & \multicolumn{2}{|c|}{$\begin{array}{l}1995-00 \\
\text { cohort }\end{array}$} \\
\hline & Year 1 & Year 10 & Year 1 & Year 10 & Year 1 & Year 10 & Year 1 & Year 10 \\
\hline $\mathrm{Yu}=$ median earnings for unconstrained sample & 140 & 442 & 208 & 636 & 317 & 769 & 560 & 1079 \\
\hline Yr=median earnings for constrained sample & 156 & 458 & 270 & 673 & 404 & 775 & 673 & 1156 \\
\hline Yr-Yu & 16 & 16 & 62 & 37 & 87 & 6 & 113 & 77 \\
\hline$(\mathrm{Yr}-\mathrm{Yu}) 1-(\mathrm{Yr}-\mathrm{Yu}) 10$ & 0 & & 24 & & 81 & & 36 & \\
\hline \multicolumn{9}{|l|}{ Native born } \\
\hline $\mathrm{Yu}=$ median earnings for unconstrained sample & 194 & 442 & 335 & 686 & 538 & 885 & 719 & 1060 \\
\hline Yr=median earnings for constrained sample & 194 & 450 & 346 & 692 & 563 & 900 & 750 & 1080 \\
\hline Yr-Yu & 0 & 8 & 12 & 6 & 24 & 15 & 31 & 20 \\
\hline$(\mathrm{Yr}-\mathrm{Yu}) 1-(\mathrm{Yr}-\mathrm{Yu}) 10$ & -8 & & 6 & & 9 & & 11 & \\
\hline \multicolumn{9}{|c|}{ Men who completed 13 or more school years and were 40-54 years old at the time of the initial census } \\
\hline & \multicolumn{2}{|c|}{$1965-70$ cohort } & \multicolumn{2}{|c|}{$1975-80$ cohort } & \multicolumn{2}{|c|}{$1985-90$ cohort } & \multicolumn{2}{|c|}{ 1995-00 cohort } \\
\hline Foreign born & Year 1 & Year 10 & Year 1 & Year 10 & Year 1 & Year 10 & Year 1 & Year 10 \\
\hline $\mathrm{Yu}=$ median earnings for unconstrained sample & 174 & 369 & 289 & 538 & 446 & 665 & 579 & 676 \\
\hline Yr=median earnings for constrained sample & 181 & 374 & 308 & 553 & 500 & 669 & 615 & 694 \\
\hline Yr-Yu & 7 & 4 & 19 & 14 & 54 & 4 & 37 & 18 \\
\hline$(\mathrm{Yr}-\mathrm{Yu}) 1-(\mathrm{Yr}-\mathrm{Yu}) 10$ & 2 & & 5 & & 50 & & 19 & \\
\hline \multicolumn{9}{|l|}{ Native born } \\
\hline $\mathrm{Yu}=$ median earnings for unconstrained sample & 242 & 426 & 462 & 690 & 738 & 865 & 923 & 934 \\
\hline Yr=median earnings for constrained sample & 242 & 430 & 467 & 692 & 750 & 865 & 930 & 939 \\
\hline Yr-Yu & 0 & 4 & 5 & 2 & 12 & 0 & 7 & 5 \\
\hline$(\mathrm{Yr}-\mathrm{Yu}) 1-(\mathrm{Yr}-\mathrm{Yu}) 10$ & -4 & & 3 & & 12 & & 2 & \\
\hline
\end{tabular}

Notes: $\left(Y_{r}-Y_{u}\right)_{1}-\left(Y_{r}-Y_{u}\right)_{10}$ is the difference between the median earnings estimated from the restricted sample (the sample excluding students) and the unrestricted sample at year 1 minus the difference between the median earnings from the restricted and unrestricted samples measured at year 10. Differences reported in the table were calculated before rounding

Excluding students decreases foreign-born relative earnings growth for the more highly educated in both age groups. With the exception of the 1965-1970 cohort, it does not decrease the relative earnings growth for the less educated. Excluding zero earners decreases foreign-born relative earnings growth for all age/education/year-ofentry groups with one exception - the young/more-educated in the 1965-1970 cohort. To understand how excluding students downward biases estimates of immigrant relative earnings growth for men with at least 13 years of schooling and how excluding zero earners does this for almost all age/education/year-of-entry groups, we examine the effects of these two restrictions, separately, for immigrants and natives.

\subsubsection{The effects of excluding students for immigrants and natives with at least 13 years of schooling}

As pictured in Fig. 5's top tier, we hypothesized that excluding students would (for the more educated) raise initial earnings relative to earnings 10 years later more for 
immigrants than for natives: $\left[\left(Y_{r}-Y_{u}\right)_{1}-\left(Y_{r}-Y_{u}\right)_{10}\right]_{F B}>\left[\left(Y_{r}-Y_{u}\right)_{1}-\left(Y_{r}-Y_{u}\right)_{10}\right]_{N B}$ wherein $Y_{u}$ and $Y_{r}$ denote the median weekly earnings estimated from unrestricted and restricted samples and FB and NB denote the foreign-born and native-born. As shown in Table 1, $\left[\left(Y_{r}-Y_{u}\right)_{1}-\left(Y_{r}-Y_{u}\right)_{10}\right]$ is greater for immigrants than for natives for all year-of-entry/age groups with at least 13 years of schooling. For the younger group in the three most recent immigrant cohorts, $\left[\left(Y_{r}-Y_{u}\right)_{1}-\left(Y_{r}-Y_{u}\right)_{10}\right]$ is at least three times the analogous difference for US natives. For the older group in the two most recent immigrant cohorts, $\left[\left(Y_{r}-Y_{u}\right)_{1}-\left(Y_{r}-Y_{u}\right)_{10}\right]$ is at least four times that for natives.

\subsubsection{The effects of excluding zero earners for immigrants and natives}

We proposed two paths for $\left[\left(Y_{r}-Y_{u}\right)_{10}-\left(Y_{r}-Y_{u}\right)_{1}\right]$ being greater for natives than for immigrants, thereby biasing downward the relative earnings growth of immigrants. One, pictured in Fig. 5's middle tier, occurs if excluding zero earners raises earnings at year 10 less than at year 1 for immigrants than for natives. As shown in Table 2 , there is not a single case where $\left[\left(Y_{r}-Y_{u}\right)_{10}-\left(Y_{r}\right.\right.$ $\left.\left.-Y_{u}\right)_{1}\right]<0$ for natives whereas we consistently find this result for young, more educated immigrants. Another path is if excluding zero earners raises the earnings in year 10 relative to year 1 more for natives than for immigrants, as depicted in Fig. 5's bottom tier. As shown in Table 2, excluding zero earners increases the earnings at year 10 relative to year 1 for all age/education/year-of-entry groups for natives, but does so to a much lesser degree or, not at all, for immigrants.

The dramatically different effects for natives and immigrants of excluding zero earners distort measures of immigrant relative earnings growth. Not excluding zero earners, immigrants have high relative earnings growth. Excluding zero earners, immigrants have low relative earnings growth because they are being compared to a more select sample of US-born men at the 10-year point than at the first-year point. These results suggest that the US-born composition to whom immigrants are compared in Borjas (1985, 1994, 1995, and 2015) changes radically over 10 years creating the illusion that post-1965 immigrants have low earnings growth relative to US natives.

\section{Skill transferability, human capital investment, and earnings growth}

The preceding analyses show that US immigrant men in the decades following the 1965 Immigration and Nationality Act experienced high earnings growth relative to US natives. ${ }^{33}$ Chiswick (1978a, 1979, 1986), Duleep and Regets (1999, 2002), and Duleep et al. (2018) assume that human capital investment

\footnotetext{
$\overline{33}$ We limit our analyses to immigrant men in part because of less complex labor force participation patterns for males, particularly over the multiple decades of our data. However, interruptions in women's full-time work experience for family reasons such as having primary responsibility for child rearing (Blau and Kahn 2013) or to aid the formation and running of a business (Duleep et al. 2021b) may actually make our measurement concerns more important for measuring immigrant earning growth.
} 
Table 2 The effect of excluding zero earners on median weekly earnings for immigrants, measured 1 to 5 years after U.S. entry and 10 years later, and for U.S. natives

Men who completed 13 or more school years and were 25-39 years old at the time of the initial census

\begin{tabular}{|c|c|c|c|c|c|c|c|c|}
\hline \multirow[b]{2}{*}{ Foreign born } & \multicolumn{2}{|c|}{$\begin{array}{l}1965-70 \\
\text { cohort }\end{array}$} & \multicolumn{2}{|c|}{$\begin{array}{l}\text { 1975-80 } \\
\text { cohort }\end{array}$} & \multicolumn{2}{|c|}{$\begin{array}{l}1985-90 \\
\text { cohort }\end{array}$} & \multicolumn{2}{|c|}{$\begin{array}{l}1995-00 \\
\text { cohort }\end{array}$} \\
\hline & $\begin{array}{c}\text { Year } \\
1\end{array}$ & $\begin{array}{r}\text { Year } \\
10\end{array}$ & $\begin{array}{c}\text { Year } \\
1\end{array}$ & $\begin{array}{r}\text { Year } \\
10\end{array}$ & $\begin{array}{c}\text { Year } \\
1\end{array}$ & $\begin{array}{r}\text { Year } \\
10\end{array}$ & $\begin{array}{c}\text { Year } \\
1\end{array}$ & $\begin{array}{r}\text { Year } \\
10\end{array}$ \\
\hline $\begin{array}{l}\text { Yu=median earnings for unrestricted } \\
\text { sample }\end{array}$ & 140 & 442 & 208 & 636 & 317 & 769 & 560 & 1079 \\
\hline $\begin{array}{l}\text { Yr=median earnings for restricted } \\
\text { sample }\end{array}$ & 155 & 456 & 250 & 672 & 385 & 800 & 675 & 1156 \\
\hline Yr-Yu & 15 & 13 & 42 & 37 & 67 & 31 & 115 & 77 \\
\hline$(\mathrm{Yr}-\mathrm{Yu}) 10-(\mathrm{Yr}-\mathrm{Yu}) 1$ & -2 & & -5 & & -37 & & -38 & \\
\hline \multicolumn{9}{|l|}{ Native born } \\
\hline $\begin{array}{l}\mathrm{Yu}=\text { median earnings for unrestricted } \\
\text { sample }\end{array}$ & 194 & 442 & 335 & 686 & 538 & 885 & 719 & 1060 \\
\hline $\begin{array}{l}\text { Yr=median earnings for restricted } \\
\text { sample }\end{array}$ & 194 & 456 & 346 & 706 & 558 & 923 & 746 & 1156 \\
\hline Yr-Yu & 0 & 14 & 12 & 20 & 19 & 38 & 27 & 96 \\
\hline$(\mathrm{Yr}-\mathrm{Yu}) 10-(\mathrm{Yr}-\mathrm{Yu}) 1$ & 14 & & 8 & & 19 & & 69 & \\
\hline
\end{tabular}

Men who completed 13 or more school years and were 40-54 years old at the time of the initial census

\begin{tabular}{|c|c|c|c|c|c|c|c|c|}
\hline \multirow[b]{2}{*}{ Foreign born } & \multicolumn{2}{|c|}{$\begin{array}{r}1965-70 \\
\text { cohort }\end{array}$} & \multicolumn{2}{|c|}{$\begin{array}{r}1975-80 \\
\text { cohort }\end{array}$} & \multicolumn{2}{|c|}{$\begin{array}{r}1985-90 \\
\text { cohort }\end{array}$} & \multicolumn{2}{|c|}{$\begin{array}{r}1995-00 \\
\text { cohort }\end{array}$} \\
\hline & $\begin{array}{c}\text { Year } \\
1\end{array}$ & $\begin{array}{r}\text { Year } \\
10\end{array}$ & $\begin{array}{c}\text { Year } \\
1\end{array}$ & $\begin{array}{r}\text { Year } \\
10\end{array}$ & $\begin{array}{c}\text { Year } \\
1\end{array}$ & $\begin{array}{r}\text { Year } \\
10\end{array}$ & $\begin{array}{c}\text { Year } \\
1\end{array}$ & $\begin{array}{r}\text { Year } \\
10\end{array}$ \\
\hline $\begin{array}{l}\text { Yu=median earnings for unrestricted } \\
\text { sample }\end{array}$ & 174 & 369 & 289 & 538 & 446 & 665 & 579 & 676 \\
\hline $\begin{array}{l}\text { Yr=median earnings for restricted } \\
\text { sample }\end{array}$ & 186 & 390 & 330 & 596 & 572 & 737 & 712 & 809 \\
\hline Yr-Yu & 12 & 21 & 42 & 58 & 126 & 71 & 133 & 133 \\
\hline$(\mathrm{Yr}-\mathrm{Yu}) 10$ - (Yr-Yu)1 & 9 & & 16 & & -55 & & 0 & \\
\hline \multicolumn{9}{|l|}{ Native born } \\
\hline $\begin{array}{l}\text { Yu=median earnings for unrestricted } \\
\text { sample }\end{array}$ & 242 & 426 & 462 & 690 & 738 & 865 & 923 & 934 \\
\hline $\begin{array}{l}\text { Yr=median earnings for restricted } \\
\text { sample }\end{array}$ & 248 & 470 & 480 & 769 & 769 & 981 & 962 & 1156 \\
\hline Yr-Yu & 6 & 44 & 18 & 79 & 31 & 115 & 38 & 222 \\
\hline$(\mathrm{Yr}-\mathrm{Yu}) 10$ - (Yr-Yu)1 & 38 & & 61 & & 84 & & 184 & \\
\hline
\end{tabular}

Men who completed less than 13 school years and were 25-39 years old at the time of the initial census

\begin{tabular}{|c|c|c|c|c|c|c|c|c|}
\hline \multirow[b]{2}{*}{ Foreign born } & \multicolumn{2}{|c|}{$\begin{array}{r}1965-70 \\
\text { cohort }\end{array}$} & \multicolumn{2}{|c|}{$\begin{array}{r}\text { 1975-80 } \\
\text { cohort }\end{array}$} & \multicolumn{2}{|c|}{$\begin{array}{r}1985-90 \\
\text { cohort }\end{array}$} & \multicolumn{2}{|c|}{$\begin{array}{r}1995-00 \\
\text { cohort }\end{array}$} \\
\hline & $\begin{array}{c}\text { Year } \\
1\end{array}$ & $\begin{array}{r}\text { Year } \\
10\end{array}$ & $\begin{array}{c}\text { Year } \\
1\end{array}$ & $\begin{array}{r}\text { Year } \\
10\end{array}$ & $\begin{array}{c}\text { Year } \\
1\end{array}$ & $\begin{array}{r}\text { Year } \\
10\end{array}$ & $\begin{array}{c}\text { Year } \\
1\end{array}$ & $\begin{array}{r}\text { Year } \\
10\end{array}$ \\
\hline $\mathrm{Yu}=$ earnings for unrestricted sample & 117 & 250 & 158 & 337 & 214 & 400 & 292 & 443 \\
\hline Yr=earnings for restricted sample & 119 & 269 & 182 & 360 & 250 & 442 & 346 & 482 \\
\hline Yr-Yu & 2 & 19 & 24 & 23 & 36 & 42 & 54 & 39 \\
\hline
\end{tabular}


Table 2 (continued)

Men who completed 13 or more school years and were 25-39 years old at the time of the initial census

\begin{tabular}{|c|c|c|c|c|c|c|c|c|}
\hline & \multicolumn{2}{|c|}{$\begin{array}{l}1965-70 \\
\text { cohort }\end{array}$} & \multicolumn{2}{|c|}{$\begin{array}{l}\text { 1975-80 } \\
\text { cohort }\end{array}$} & \multicolumn{2}{|c|}{$\begin{array}{l}1985-90 \\
\text { cohort }\end{array}$} & \multicolumn{2}{|c|}{$\begin{array}{l}\text { 1995-00 } \\
\text { cohort }\end{array}$} \\
\hline$(\mathrm{Yr}-\mathrm{Yu}) 10-(\mathrm{Yr}-\mathrm{Yu}) 1$ & 17 & & -1 & & 7 & & -15 & \\
\hline \multicolumn{9}{|l|}{ Native born } \\
\hline $\mathrm{Yu}=$ earnings for unrestricted sample & 145 & 308 & 269 & 442 & 365 & 538 & 480 & 540 \\
\hline $\mathrm{Yr}=$ earnings for restricted sample & 148 & 330 & 285 & 481 & 396 & 604 & 529 & 694 \\
\hline Yr-Yu & 3 & 22 & 16 & 38 & 30 & 66 & 49 & 154 \\
\hline$(Y r-Y u) 10-(Y r-Y u) 1$ & 19 & & 22 & & 35 & & 105 & \\
\hline
\end{tabular}

Men who completed less than 13 school years and were 40-54 years old at the time of the initial census

\begin{tabular}{|c|c|c|c|c|c|c|c|c|}
\hline \multirow[b]{2}{*}{ Foreign born } & \multicolumn{2}{|c|}{$\begin{array}{r}1965-70 \\
\text { cohort }\end{array}$} & \multicolumn{2}{|c|}{$\begin{array}{r}1975-80 \\
\text { cohort }\end{array}$} & \multicolumn{2}{|c|}{$\begin{array}{r}1985-90 \\
\text { cohort }\end{array}$} & \multicolumn{2}{|c|}{$\begin{array}{r}1995-00 \\
\text { cohort }\end{array}$} \\
\hline & $\begin{array}{c}\text { Year } \\
1\end{array}$ & $\begin{array}{r}\text { Year } \\
10\end{array}$ & $\begin{array}{c}\text { Year } \\
1\end{array}$ & $\begin{array}{r}\text { Year } \\
10\end{array}$ & $\begin{array}{c}\text { Year } \\
1\end{array}$ & $\begin{array}{r}\text { Year } \\
10\end{array}$ & $\begin{array}{c}\text { Year } \\
1\end{array}$ & $\begin{array}{r}\text { Year } \\
10\end{array}$ \\
\hline $\mathrm{Yu}=$ earnings for unrestricted sample & 113 & 215 & 165 & 288 & 222 & 333 & 308 & 385 \\
\hline Yr=earnings for restricted sample & 117 & 236 & 194 & 346 & 269 & 404 & 365 & 462 \\
\hline Yr-Yu & 4 & 22 & 30 & 58 & 47 & 71 & 58 & 77 \\
\hline$(\mathrm{Yr}-\mathrm{Yu}) 10-(\mathrm{Yr}-\mathrm{Yu}) 1$ & 18 & & 28 & & 24 & & 19 & \\
\hline \multicolumn{9}{|l|}{ Native born } \\
\hline $\mathrm{Yu}=$ earnings for unrestricted sample & 155 & 250 & 308 & 365 & 462 & 442 & 538 & 423 \\
\hline Yr=earnings for restricted sample & 155 & 317 & 334 & 500 & 506 & 635 & 625 & 732 \\
\hline Yr-Yu & 0 & 67 & 26 & 135 & 45 & 192 & 87 & 309 \\
\hline$(Y r-Y u) 10-(Y r-Y u) 1$ & 67 & & 108 & & 147 & & 223 & \\
\hline
\end{tabular}

Notes: $(\mathrm{Yr}-\mathrm{Yu})_{10}-(\mathrm{Yr}-\mathrm{Yu})_{1}$ is the difference between the median earnings estimated from the restricted sample (the sample excluding zero earners) and the unrestricted sample at year 10 minus the difference between the median earnings from the restricted and unrestricted samples measured at year 1. Differences reported in the table were calculated before rounding

underlies earnings growth and that differences in human capital investment between immigrants and natives, and among immigrants, stem from differences in the degree to which immigrants' skills transfer to the US labor market. ${ }^{34} \mathrm{We}$ further assume that the adjusted earnings gap - the difference between an immigrant's earnings and that of natives of similar age and education levelis the best measure of skill transferability and that human capital investment, given its myriad difficult-to-measure forms, is best measured by earnings growth.

Seeking a more tangible measure of skill transferability, scholars such as Akresh (2007) and Borjas (2015) use English proficiency. English proficiency, however, captures but one aspect of skill transferability whereas the adjusted earnings gap embodies all aspects of skill-transferability, measured and unmeasured. Moreover, the relationship between English proficiency and skill

\footnotetext{
${ }^{34}$ Cortes (2004), Duleep and Regets (1999), and Duleep et al. (2021b) also emphasize the importance of permanence.
} 
transferability does not occur in a vacuum. The source-country skills of some immigrants who speak English poorly may transfer well because their English proficiency affects the work they pursue and where they live. Korean immigrants with poor English fluency have high self-employment rates $^{35}$; the initial earnings of Japanese immigrants, who have low English proficiency, are high ${ }^{36}$; Mexican immigrants who speak English poorly move to areas with large Spanish-speaking enclaves. ${ }^{37}$ Conversely, the skills of immigrants who speak English perfectly may not transfer well if such individuals escape constraints to come to the US (or other economically developed countries) even when it means starting a new career.

The program under which immigrants enter the US may provide a "tangible" but less problematic measure of skill transferability than English proficiency. By its very nature-based on an employer's willingness to participate in a labor certification process - employment-based immigrants have skills immediately valued by employers, in contrast to persons entering the USA via family-based visas. Studies in Canada and the USA find that, controlling for age and education, immigrants who enter on a family visa have lower entry earnings but higher earnings growth than persons who enter via an employment visa. ${ }^{38}$

Updating previous results, we use immigrant admissions' data from the 1993-1998 Immigration and Naturalization Service public use files to estimate multinomial logits of the probabilities that an immigrant would be in each of 14 different admission categories based upon their age, sex, and country of birth. Using these logit parameter estimates, we calculated probabilities of admission type for individuals in the 1995-2000 entry cohort on the 2000 decennial census and the 2008 American Community Survey. We calculated the probability of family admission as the sum of the probabilities of the four family admissions categories. Confirming earlier studies, immigrants who are likely family-based have lower initial earnings and higher earnings growth than immigrants who are likely employment-based. ${ }^{39}$

But does this higher earnings growth represent human capital investment? And, if so, does it simply reflect learning English?

The census school-attendance question is one indicator of human capital investment. Since it asks only about participation in degree or high school diploma programs it will

\footnotetext{
${ }^{35}$ Refer to Duleep et al. (2021a).

${ }^{36}$ Duleep et al. (2021b) explore why.

${ }^{37}$ Refer to Bauer et al. (2005).

${ }^{38}$ Using different data sets, Jasso and Rosenzweig (1995), Duleep and Regets (1996a, 1996b), and DeSilva (1997) find that family-based immigrants start their host-country lives with lower earnings than their employment-based statistical twins but have higher earnings growth; with time, their earnings converge.

${ }^{39}$ While we focus in section 5 on likely differences between immigrants admitted via work visas versus those with family sponsorship, many other factors can affect the incentives and the ability to work or invest in human capital. For example, the spouses of most types of work-visa holders are either forbidden to work or find work authorization difficult. Duleep et al. (2021a) find that the larger the initial adjusted earnings gap for men, the more likely that women work. Yet, this relationship may reflect, at least in part, work restrictions for spouses of work-visa holders. Untangling these issues requires data that more closely links visa information with work history. One exciting possibility would be to link information from individual visas to earnings data in the Social Security administrative record systems.
} 
not include those enrolled only in English language courses, in occupational certificate programs, or on-the-job training. ${ }^{40}$

Relating school attendance to the probability that an immigrant was admitted by a family versus employment-based visa reveals that family-based immigrants are more likely to attend school than employment-based immigrants (Fig. 7). ${ }^{41}$ With the caveat that attending school is only one form of human capital investment (and not necessarily the most important one), this result supports the hypothesis that because of skilltransferability issues, immigrants with low initial earnings (given their age and atentry education levels) will be more likely to invest in human capital than other immigrants or natives of similar age and education.

\section{Conclusion}

The success of immigrants in the USA, or other receiving countries, has long been the focus of important policy discussions. The 1965 Immigration and Nationality Act, emphasizing family sponsorship, allowed immigrants from a more diverse set of countries than had characterized US immigration in the four decades preceding it. Whereas the earlier immigrants earned on par with US natives of comparable age and education, the initial earnings of post-1965 immigrants lie far below the earnings of their US-born statistical twins.

Initial earnings, however, poorly predict the economic contribution immigrants make to the US economy, or their eventual social and economic status. Rapid earnings growth accompanies low initial earnings caused by low initial skill transferability. High earnings growth affects more than immigrants' lifetime earnings: a pattern of upward intragenerational mobility mitigates social problems often associated with low incomes.

High earnings growth may also signify something else about the economic contribution of immigrants to receiving countries. Human capital that is not immediately valued in the host country's labor market is useful for learning new skills. To find a niche in their new economy, immigrants adapt and increase their human capital fueling innovation and flexibility. ${ }^{42}$ The consequences of low earnings associated with high human-capital investment differ profoundly from the social and economic consequences of low earnings associated with low ability.

The methodologies economists use to measure immigrant economic assimilation underestimate the earnings growth of immigrants who start with low earnings relative to US natives. One problem stems from not allowing earning growth to vary with entry earnings. Human capital theory and much empirical work suggest that the initial earnings of immigrants, adjusted for age and education, inversely relate to earnings growth rates.

\footnotetext{
$\overline{40}$ Since it asks whether individuals currently attend school it also avoids compositional change problems associated with inferring human capital investment by measuring changes in educational achievement by following cohorts.

${ }^{41}$ Figure 7 shows school attendance as a function of age and the probability of being a family-based immigrant (which is a function of country of birth, age, and year of immigration). The graphical results are evaluated at the mean level of schooling for immigrants. In other work, we find a positive relationship between family admissions and school attendance at all schooling levels. However, the higher the education level, the greater the effect of family-based admission on school attendance, consistent with the IHCI model described in Duleep and Regets (2002).

42 On this topic, see Green (1999) and Duleep et al. (2021a).
} 

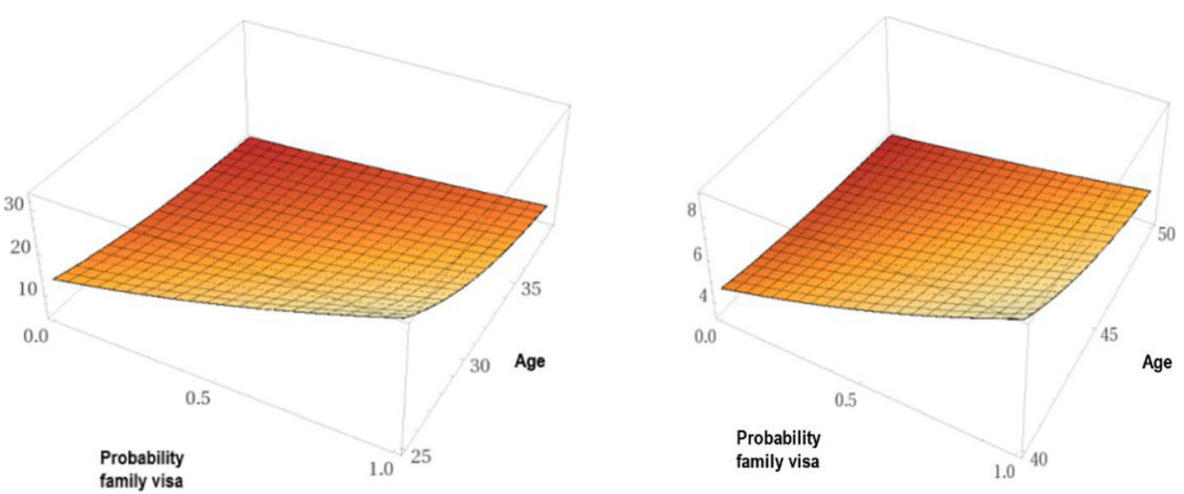

Fig. 7 Estimated in-school rate in 2000 for immigrants entering the USA in 1993-1998 by age and probability of family visa

Another problem, for studies that follow cohorts across censuses, is when a control or stratification variable (such as years of schooling) can only be measured the time of each census. ${ }^{43}$ Finally, when following cohorts, the sample exclusions used by labor economists downward bias the relative earnings growth of immigrants who begin with low initial earnings.

Excluding zero earners is a staple of labor economics, sociology, and demography given a reliance on Mincer earnings equations wherein the dependent variable is the logarithm of earnings. Their exclusion does not cause a bias problem in analyses that follow the same individuals: Duleep and Dowhan (2002) and Duleep and Regets (1997) exclude zero earners. If, however, analysts do not follow the same individuals then excluding zero earners likely understates the earnings growth of US immigrants relative to that of US natives.

The following guidelines summarize suggestions for estimating immigrant earnings growth. Each of these guidelines will have exceptions for specific analytic purposes. They are, however, a good starting point for measuring immigrant economic adaptation and earnings growth:

- When analyzing cohorts over time, include only those who can be tracked from near their initial year of migration.

- Follow each entry cohort separately, not constraining growth rates to be the same across cohorts.

- Be aware that education measured years after migration is not the same as at entry.

- Minimize sample exclusions when following cohorts. Include students, the selfemployed, and zero earners.

While these recommendations generally apply to all immigrants, their importance for accurately measuring immigrant earnings growth for a given group

\footnotetext{
$\overline{43}$ This will also be a problem with longitudinal data if analysts do not or cannot carry information on the same individual from one observation period to the next.
} 
depends on the propensity to invest in human capital for that group; the higher this propensity, the greater the relevance of our suggested strategies. Beginning research suggests that key determinants of the propensity to invest in human capital appear to be the degree to which immigrants are permanently attached to the USA - the greater the permanence, the greater the propensity to invest; the country of origin's level of economic development-immigrants from less economically developed countries are more likely to invest in human capital than those from more economically developed countries; and the education level of immigrants (Duleep et al. 2021a). ${ }^{44} 45$

In conclusion, following immigrant cohorts from their beginning years in the USA, imposing no sample restrictions, and letting earnings growth vary with entry earnings reveals high earnings growth of immigrant men relative to US natives in the decades following the 1965 Immigration and Nationality Act.

Acknowledgements We are grateful for help on this paper and previous efforts leading up to this paper from Robert Gesumaria, Patrice Cole, Barry Chiswick, Daniel Dowhan, Cordelia Reimers, Dave Shoffner, Christopher Tamborini, Andrés Villarreal, and Polina Vlasenko. We are also grateful to three anonymous referees and the Editor, Klaus F. Zimmermann, for their help and guidance in the reviewing process. The usual disclaimers apply.

\section{Declarations}

Conflict of interest The authors declare no competing interests.

Open Access This article is licensed under a Creative Commons Attribution 4.0 International License, which permits use, sharing, adaptation, distribution and reproduction in any medium or format, as long as you give appropriate credit to the original author(s) and the source, provide a link to the Creative Commons licence, and indicate if changes were made. The images or other third party material in this article are included in the article's Creative Commons licence, unless indicated otherwise in a credit line to the material. If material is not included in the article's Creative Commons licence and your intended use is not permitted by statutory regulation or exceeds the permitted use, you will need to obtain permission directly from the copyright holder. To view a copy of this licence, visit http://creativecommons.org/licenses/by/4.0/.

\footnotetext{
$\overline{44}$ The effect of allowing earnings growth to vary with entry earnings on estimates of immigrant earnings growth will depend on how immigrant entry earnings, within age and education groups, have varied over time. With a decrease in entry earnings, the fixed-cohort-effect methodology underestimates the actual earnings growth of the more recent cohorts. This is the case for immigrants originating from economically developing Asian countries following the 1965 Immigration and Nationality Act (Duleep et al., 2021b). Conversely, when the (adjusted) entry earnings increase from earlier to more recent cohorts, the fixed-cohort-effect methodology overestimates actual earnings growth. This is the case for certain age-education groups of European immigrants (Duleep et al., 2021a).

${ }^{45}$ Our analysis focuses on men only. A challenge of extending our work to immigrant versus U.S.-born women is that experience is on average overstated for women given interruptions in their work histories thus leading to smaller than true earnings function gradients (Polachek, 2008). For the participation decision, Blau et al. (2011) highlight the role of country-of-origin culture in determining the U.S. labor force participation of immigrant women. Examining fewer countries, Duleep et al. (2021b) document startling disconnects between source-country cultures and the U.S. labor force participation of immigrant women. The varying results highlight the need for further efforts to untangle underlying causalities in the role of women in the economic assimilation of immigrants.
} 


\section{References}

Akresh IR (2006) Occupational mobility among legal immigrants to the United States. Int Migr Rev 40(4): 854-884

Akresh IR (2007) U.S. immigrants' labor market adjustment: additional human capital investment and earnings growth. Demography 44(4):865-881

Akresh IR (2008) Occupational trajectories of legal U.S. immigrants: downgrading and recovery. Popul Dev Rev 34(3):435-456

Aydemir A, Skuterud M (2005) Explaining the deteriorating entry earnings of Canada's immigrant cohorts, 1966-2000. Can J Econ 38(2):641-671

Bauer T, Epstein GS, Gang IN (2005) Enclaves, language and the location choice of migrants. J Popul Econ 18(4):649-662

Benjamin, D., Gunderson, M., Lemieux, T., \& Riddell, C. (2017). Labour market economics

Bernard WS (1980) Immigration: History of U.S. Policy. In: Thernstrom S (ed) Harvard Encyclopedia of American Ethnic Groups. Belknap Press, Cambridge, Mass, pp 486-495

Betts, J. R., and M. Lofstrom. "The Educational Attainment of Immigrants: Trends and Implications. Issues in the Economics of Immigration. G. Borjas." (2000)

Blau F, Kahn L (2013) The feasibility and importance of adding measures of actual experience to crosssectional data collection. J Labor Econ 31(2):S17-S58

Blau F, Kahn L, Papps K (2011) Gender, source country characteristics, and labor market assimilation among immigrants. Rev Econ Stat 93(1):43-58

Bodvarsson OB, Van den Berg H (2013) The Economics of Immigration Theory and Policy, 2nd edn. Springer, New York, Heidelberg, Dordrecht, London

Borjas G (1985) Assimilation, changes in cohort quality, and the earnings of immigrants. J Labor Econ 3:463489

Borjas G (1987) Self-selection and immigrants. Am Econ Rev 77:531-553

Borjas G (1992a) National origin and the skills of immigrants. In: Borjas GJ, Freeman RB (eds) Immigration and the work force. University of Chicago Press, Chicago

Borjas, George. "Immigration research in the 1980s: A turbulent decade." Research frontiers in industrial relations and human resources (1992): 417-446

Borjas G (1992c) National origin and the skills of immigrants. In: Borjas GJ, Freeman RB (eds) Immigration and the work force. National Bureau of Economic Research. University of Chicago Press, Chicago, pp $17-48$

Borjas G (1994) The economics of immigration. J Econ Lit 1667-1717(December)

Borjas G (1995) Assimilation and changes in cohort quality revisited: what happened to immigrant earnings in the 1980s? J Labor Econ 13(2):201-245

Borjas, George J. "The economic analysis of immigration." Handbook of labor economics 3 (1999): 16971760

Borjas, G. J. (2008). 1. The Economic Progress of Immigrants (pp. 15-50). University of Chicago Press

Borjas G (2014) Immigration economics. Harvard University Press, Cambridge, MA

Borjas G (2015) The slowdown in the economic assimilation of immigrants: aging and cohort effects revisited again. J Hum Cap 9(4):483-517

Borjas George, 2016. Labor economics, 7th edition, McGraw Hill Education

Borjas George, 2020. Labor Economics, international students edition, 8th edition, McGraw Hill Education

Borjas G, Tienda M (1987) The economic consequences of immigration. Science 235:646-651

Chiswick B (1978a) The effect of americanization on the earnings of foreign-born men. J Polit Econ 86(5): 897-922

Chiswick Barry, 1978b. "A longitudinal analysis of occupational mobility of immigrants," in ed. Barbara Dennis, Proceedings of the 30th Annual Winter Meeting, Industrial Relations Research Association, December, 1977, Madison, Wisconsin, 20-27

Chiswick B (1979) The economic progress of immigrants: some apparently universal patterns. In: Fellner W (ed) Contemporary Economic Problems. American Enterprise Institute, Washington, D.C., pp 359-399

Chiswick B (1986) Is the new immigration less skilled than the old? J Labor Econ 4(2):168-192

Chiswick B, DebBurman N (2004) Educational attainment: analysis by immigrant generation. Econ Educ Rev 23:361-379

Chiswick B, Miller P (2008) Occupational attainment and immigrant economic progress in Australia. Econ Rec 84(s1):S45-S56 
Chiswick B, Lee YL, Miller P (2005) Longitudinal analysis of immigrant occupational mobility: a test of the immigrant assimilation hypothesis. Int Migr Rev 39(2):332-353

Cortes KE (2004) Are refugees different from economic immigrants? Some empirical evidence on the heterogeneity of immigrant groups in the United States. Rev Econ Stat 86(2):465-480

Demombynes, G. M. (2002, January). Three Ways of Looking at Immigrant Wage Growth: Analysis with the 1993-1998 Current Population Survey. In Prepared for the Institute for Labor and Employment Conference (pp. 18-19)

DeSilva A (1997) Earnings of immigrant classes in the early 1980's in Canada: a re-examination. Can Public Policy/Analyse de Politiques 23(2):179-202

Duleep, Harriet Orcutt, and Mark C. Regets. "The elusive concept of immigrant quality: evidence from 19701990." Available at SSRN 003129 (2002)

Duleep, Harriet Orcutt and Daniel J. Dowhan, 2002. "Insights from Longitudinal Data on the Earnings Growth of U.S. Foreign- Born Men,” Demography 39(3):485-506.

Duleep H, Regets M (1994) The elusive concept of immigrant quality: evidence from 1960-1980. In: 1992 American Economic Association version), PRIP-UI-28. Urban Institute, Washington, DC

Duleep H, Regets M (1996a) Admission criteria and immigrant earnings profiles. Int Migr Rev 30(2):571-590

Duleep H, Regets M (1996b) Family unification, siblings, and skills. In: Duleep H, Wunnava PV (eds) Immigrants and immigration policy: individual skills, family ties, and group identities. JAI Press, Greenwich, CT, pp 219-244

Duleep H, Regets M (1997) Measuring immigrant wage growth using matched CPS files. Demography 34(2): 239-249

Duleep H, Regets M (1999) Immigrants and human capital investment. Am Econ Rev 89(2):186-191

Duleep Harriet and Regets Mark. 2002. "The elusive concept of immigrant quality: evidence from 1970-1990, "IZA Discussion Paper \#631

Duleep, Harriet Orcutt, Xingfei Liu, and Mark C. Regets. "Country of Origin, Earnings Convergence, and Human Capital Investment: A New Method for the Analysis of US Immigrant Economic Assimilation." Global Labor Organization Discussion Paper 247 (2018)

Duleep, Harriet Orcutt, David A. Jaeger, and Peter McHenry. "On immigration and native entrepreneurship." Global Labor Organization Discussion Paper 846 (2021a)

Duleep, H., Regets, M. C., Sanders, S., \& Wunnava, P. V. (2021b). Human Capital Investment: A History of Asian Immigrants and Their Family Ties. Springer Nature.

Friedberg, Rachel. "The labor market assimilation of immigrants in the US: The role of age at arrival." Brown University (1993): 49-79.

Green DA (1999) Immigrant occupational attainment: assimilation and mobility over time. J Labor Econ 17(1):49-79

Green DA, Worswick C (2012) Immigrant earnings profiles in the presence of human capital investment: measuring cohort and macro effects. Labour Econ 19(2):241-259

Hall M, Farkas G (2008) Does human capital raise earnings for immigrants in the low-skill labor market? Demography 45(3):619-639

$\mathrm{Hu}$, Wei-Yin. "Immigrant earnings assimilation: estimates from longitudinal data." American Economic Review 90.2 (2000): 368-372

Hutchinson, Edward Prince. Legislative history of American immigration policy, 1798-1965. University of Pennsylvania Press, 2016

Jasso G, Rosenzweig MR (1990) The new chosen people: immigrants in the United States. Russell Sage Foundation, New York

Jasso G, Rosenzweig MR (1995) Do immigrants screened for skills do better than family-reunification immigrants? Int Migr Rev 29:85-111

Kossoudji SA (1989) Immigrant worker assimilation: is it a labor market phenomenon? J Hum Resour 24(3): 494-527

Lalonde RJ, Topel RH (1991) Immigrants in the American labor market: quality, assimilation, and distributional effects. Am Econ Rev 81(2):297-302

Lalonde RJ, Topel RH (1997) Economic Impact of International Migration and the Economic Performance of Migrants. In: Rosenzweig MR, Stark O (eds) Handbook of Population and Family Economics. Elsevier, Amsterdam, pp 800-850

Lin C (2013) Earnings gap, cohort effect and economic assimilation of immigrants from Mainland China, Hong Kong, and Taiwan in the United States. Rev Int Econ 21(2):249-265

Lofstrom Magnus, 2000. "Self-employment and earnings among high-skilled immigrants in the United States." Cornelius WA and Espenshade TJ (eds.), The International Migration of the Highly Skilled: Demand, Supply and Development Consequences, La Jolla, CA, 163-195 
Lofstrom M (2002) Labor market assimilation and the self-employment decision of immigrant entrepreneurs. J Popul Econ 15(1):83-114

Lofstrom M (2011) Low-skilled immigrant entrepreneurship. Rev Econ Househ 9(1):25-44

Lubotsky D (2007) Chutes or ladders? A longitudinal analysis of immigrant earnings. J Polit Econ 115(5): 820-867

McKenzie RD (1928) Oriental exclusion: the effect of American immigration laws, regulations, and judicial decisions upon the Chinese and Japanese on the American-Pacific Coast. Univ. of Chicago Press, Chicago, Ill

Schoeni RF (1997) New evidence on the economic progress of foreign-born men in the 1970s and 1980s. J Hum Resour 32(4):683-740

Van Tubergen F, van de Werfhorst H (2007) Post-immigration investments in education: a study of immigrants in the Netherlands. Demography 44(4):883-898

Villarreal A, Tamborini C (2018) Immigrants' economic assimilation: evidence from longitudinal earnings records. Am Sociol Rev 83(4):686-715

Walker, Francis A. "Restriction of immigration." Atlantic Monthly 77.464 (1896): 822-829

Zorlu A (2013) Occupational adjustment of immigrants in the Netherlands. J Int Migr Integra 14(4):711-731

Publisher's note Springer Nature remains neutral with regard to jurisdictional claims in published maps and institutional affiliations. 